\title{
Tilanpidon vakiinnuttaminen: Yritystoimintaansa kehittävien ja vakiinnuttavien viljelijöiden selviytymisstrategioita
}

\author{
Leena Rantamäki-Lahtinen ${ }^{1)}$ ja Minna Väre ${ }^{2)}$ \\ MTT Taloustutkimus \\ Latokartanonkaari 9, 00790 Helsinki \\ 1) leena.rantamaki-lahtinen@mtt.fi, 2)minna.vare@mtt.fi
}

\section{Tiivistelmä}

Sukupolvenvaihdoksen on todettu aikaisemmissa tutkimuksissa vaikuttavan positiivisesti tilan kasvuun. Siitä, miten tilat selviytyvät aloitusvaiheen jälkeen, ei ole kuitenkaan olemassa kovin paljoa tietoa. Tässä tutkimuksessa tarkastellaan sitä, miten hiljattain tilanpidon aloittaneet viljelijät eroavat kokeneemmista kollegoistaan joidenkin tilan liikkeenjohdon kannalta olennaisten tekijöiden suhteen. Tarkasteltavia tekijöitä ovat $\mathrm{mm}$ tilan ja viljelijän ominaisuudet, strategiset tavoitteet ja kehittämissuunnitelmat. Tutkimusaineisto kerättiin postikyselynä Lounais-Suomessa sijaitsevan Salon kaupungin alueelta. Tilat jaettiin tutkimuksessa kolmeen ryhmään viljelijän iän ja yrittäjäkokemuksen perusteella.

Tulosten mukaan tilanpitoa aloittavilla viljelijöillä on joillakin osa-alueilla paremmat edellytykset toimia yrittäjänä kuin vanhemmilla viljelijöillä. Nuoremmilla viljelijöillä on parempi koulutus ja paremmat verkostot kuin muilla viljelijöillä. Lisäksi nuoremmat viljelijät pitävät verkostojaan tärkeämpinä kuin vanhemmat kollegansa.

Kuten olettaa saattoi, aloittelevat viljelijät olivat investoineet enemmän ja heillä oli enemmän velkaa kuin muilla viljelijöillä. Aloittelevat viljelijät myös kehittivät tilaansa muita viljelijöitä aktiivisemmin. Tilanpidon lopetteluvaiheesa olevat viljelijät taas olivat vähiten aktiivisia, jopa vaikka heillä olisi ollut sukupolvenvaihdossuunnitelmia seuraavien vuosien aikana. Tämä saattaa olla ongelmallista myös tilanpitoa jatkavan nuoren viljelijän kannalta. Tilan elinvoimaisuuden säilyttämiseksi tiloja tulisi kuitenkin kehittää jatkuvasti.

Asiasanat: liikkeenjohto, monimuuttujamenetelmät 


\section{Johdanto}

Uusien yritysten syntyminen ja perheyritysten sukupolvenvaihdokset ovat elintärkeitä maaseudun elinvoimaisena säilymisen kannalta. Toteutuneen sukupolvenvaihdoksen on myös todettu vaikuttavan positiivisesti yrityksen kasvuun muutaman vuoden vakiintumisvaiheen jälkeen (Diwisch ym. 2009). Sukupolvenvaihdoksen on todettu vaikuttavan positiivisesti erityisesti päätoimitilojen kasvuun (Weiss 1999).

Yritystoiminnan aloittamista tuetaan erilaisilla politiikkakeinoilla ja maaseudun kehittämistoimilla. Esimerkiksi viljelijöiden luopumistukijärjestelmien on todettu olevan erittäin tärkeitä maatilojen sukupolvenvaihdosten toteutumisen kannalta (Väre 2007, Hirvi 2004a). Myös yritystoiminnan aloittamista tuetaan erilaisin keinoin, kuten aloitustukien ja -lainojen avulla (InnoSuomi 2008). Näillä järjestelmillä on suuri merkitys myös yritysten kannattavuuden, jatkuvuuden ja kilpailukyvyn kannalta.

Maatilojen menestymisestä aloitusvaiheen jälkeen ei ole kuitenkaan olemassa tarpeeksi tietoa. Aikaisemmissa tutkimuksissa on tarkasteltu $\mathrm{mm}$ tilojen sukupolvenvaihdoksia sekä nuorten viljelijöiden tulorakennetta (esim. Hirvi 2004b). Sen sijaan siitä, miten viljelijät kehittävät tilaansa sukupolvenvaihdoksen jälkeen tai miten heidän tilansa menestyvät muutama vuosi yritystoiminnan aloittamisen jälkeen, on olemassa vain vähän tutkimustietoa.

Littunen ym. (2008) ovat tarkastelleet uusien yritysten menestymistä sekä siihen vaikuttavia tekijöitä. Heidän tutkimuksessaan ensimmäisten kolmen vuoden oletettiin olevan kriittisiä yrityksen jatkuvuuden kannalta. Tämän tutkimuksen mukaan aloitusvaiheen suunnittelu, ja sitä kautta myös yrittäjän ominaisuudet, vaikuttavat ratkaisevasti yritystoiminnan menestymiseen tai epäonnistumiseen. Samoin Goldberg (1996) on todennut alan lyhyen ja pitkän aikavälin näkymien lisäksi myös jatkajan taustalla ja kokemuksella olevan merkitystä. Goldberg (1996) myös toteaa tehokkaiden sukupolvenvaihdosjatkajien hyötyvän monipuolisista verkostoistaan (konsultit, neuvojat, perheenjäsenet).

Elinkaarimallien mukaan yritys kehittyy murrosvaiheiden kautta. Maatilan sukupolvenvaihdos on tyypillinen esimerkki tästä. Maatilan siirtyessä jatkajalle, tilalla tyypillisesti aloitetaan myös uusia toimintoja ja/tai vanhoja toimintoja kehitetään tai muutetaan (Rantamäki-Lahtinen 2007). Esimerkiksi noin 18:1la \% tiloista, joilla tehtiin sukupolvenvaihdos vuosina 2004-2008, on vaihdettu tuotantosuuntaa sen jälkeen. Useimmiten näillä tiloilla on luovuttu kotieläintuotannosta ja keskitytty kasvintuotantoon (63\% tuotantosuuntaa vaihtaneista tiloista) (Väre 2010).

Useimmat viljelyn aloitusvaihetta käsittelevät tutkimukset ovat keskittyneet sukupolvenvaihdosprosessin, sen toteutumisen (esim. Kimhi ja Lopez 1999) tai tilanpidon aloittavien viljelijöiden tarkasteluun. Tässä tutkimuksessa sen sijaan selvitetään miten tilanpidon hiljattain aloittaneen viljelijät eroavat kokeneemmista viljelijöistä eräiden tärkeimpien liikkeenjohdon osaalueiden (esim. tilan ja viljelijän ominaisuudet, strategiset tavoitteet ja kehittämissuunnitelmat) suhteen.

\section{Aineisto ja menetelmät}

Tutkimusaineisto kerättiin postikyselynä Lounais-Suomesta, Salon kaupungin alueelta, marraskuussa $2010^{1}$. Kysely lähetettiin kaikille alueen viljelijöille $(\mathrm{N}=1250)$. Vastausprosentti oli $19 \%(\mathrm{~N}=237)$, mitä voidaan pitää tyypillisenä sillä viljelijöille ei lähetetty muistutusta. Aineiston analysoinnissa käytettiin hyväksi $\chi^{2}$ - testiä, Kruskall-Wallisin testiä, exploratiivista faktorianalyysia sekä ryhmittelyanalyysiä. Käytetyt muuttujat valittiin olemassa olevien teorioiden perusteella. Lisäksi tutkimuksessa käytetyt kyselylomakkeet testattiin ennakkoon huolellisesti.

Tutkimusaineiston alueellisen luonteen sekä monimuuttujamenetelmien subjektiivisuuden takia tuloksia ei voida sellaisenaan yleistää koskemaan kaikkia Suomen maanviljelijöitä. Tulokset edustavat kuitenkin viljelypinta-alalla ja maataloustuotannon laajuudella mitattuna yhden maamme tärkeimmän

\footnotetext{
${ }^{1}$ Sama kysely lähetettiin myös alueen muille pienyrityksille, mutta tässä tutkimuksessa keskitytään tarkastelemaan viljelijöitä.
} 
maatalousalueen viljelijöitä. Maataloustuotannolla on suuri merkitys Salon alueella johtuen sekä edullisiin tuotanto-olosuhteisiin nojaavasta vahvasta maatalousperinteestä että sen suuresta taloudellisesta merkityksestä (tulo- ja tukivirroilla mitattuna). Lisäksi voidaan olettaa että tutkimuksen tulokset, esimerkiksi aloittelevien viljelijöiden kohtaamat ongelmat, eivät riipu tilan sijainnista.

\section{Tulokset ja tulosten tarkastelu}

Tutkimusaineiston tilat jaettiin ryhmittelyanalyysin avulla kolmeen luokkaan yrittäjän iän ja yrittäjäkokemuksen avulla. Pelkän yrittäjän iän mukaan tehty luokittelu ei ole yksinään riittävä, sillä osa viljelijöistä aloittaa yrittäjänä 20 -vuotiaana, mutta osa vasta jopa yli 40 -vuotiaana. Toisaalta myöskään pelkkään kokemukseen perustuva jaottelu ei ole riittävä, sillä se ei ota huomioon yrittäjän elämänvaihetta. Tässä tutkimuksessa tarkastelu tehtiin vastaavalla tavalla kuin Ondersteijn ym. (2003) tutkimuksessa, jossa viljelijän iän vaikutusta luokitteluun korjattiin ottamalla huomioon tilan elinkaaren vaihe. Tilat ryhmiteltiin k-means -proseduurin avulla 2 - 4 luokkaan hyödyntäen kahta muuttujaa: vastaajan ikä (vuotta) ja yrittäjäkokemus (vuotta). Ryhmittely kolmeen luokkaan oli selkeä ja se seurasi Nalsonin (1968) havaintoja perheen ja maatilan yhteydestä (ref. Gasson ja Errington 1993). Ryhmittelyanalyysin tulosten tulkinnan helpottamiseksi tehty erotteluanalyysi tuki tehtyä kolmen ryhmän valintaa.

Ensimmäinen ryhmä nimettiin "aloitusvaiheeksi" $(n=64)$. Tämän ryhmän viljelijät olivat keskimäärin nuorimpia ja heillä oli vähiten kokemusta (taulukko 1). "Keskivaiheessa" $(n=86)$ olevat viljelijät olivat keski-ikäisiä ja heillä oli enemmän yrittäjäkokemusta kuin aloitusvaiheessa olevilla viljelijöillä. Myöhäisessä/lopettamisvaiheessa" $(n=93)$ olevat viljelijät olivat vanhimpia ja heillä oli kaikkein pisin yrittäjäkokemus. Taulukossa 1 on kuvattu ryhmien eroja ja ominaisuuksia eräiden taustamuuttujien avulla. Nuorimmilla viljelijöillä oli muihin verrattuna korkeampi koulutus, he olivat investoineet enemmän ja heidän tiloillaan oli enemmän velkaa suhteessa liikevaihtoon.

\section{Strategiset tavoitteet}

Tässä tutkimuksessa viljelijöiden oletetaan olevan monitavoitteisia päätöksentekijöitä. Aiemmin on havaittu, että taloudellisten tavoitteiden ohella viljelijät arvostavat päätöksenteossaan myös muita asioita, kuten hyvää perhe-elämää ja mahdollisuutta jatkaa elämäntapaansa (Cuykendal et al. 2002). Kyselyssä oli mukana 11 kysymyksen patteri koskien erilaisia strategisia tavoitteita. Lisäksi kysyttiin, miten hyvin vastaajat kokivat saavuttaneensa asetetut tavoitteet. Strategisten tavoitteiden osalta tehtiin eksploratiivinen faktorianalyysi, ja analyysin tuloksena saatuja faktoripisteitä käytettiin hyväksi myöhemmissä analyyseissä. Tavoitteissa onnistumista mitattiin vastaavista muuttujista rakennettujen summamuuttujien avulla.

Ennen faktorianalyysin tekoa aineistolle tehtiin reliabiliteetti -analyysi. Analyysin perusteella Cronbachin Alfa $(\alpha)$ oli 0,82, joten kaikkien 11 muuttujan reliabiliteetti oli riittävä aineiston kannalta. Menetelmänä käytettiin pääakselifaktorointia ja Varimax rotaatiota. Tuloksena oli 3 faktorin malli, joka selitti $49 \%$ alkuperäisten muuttujien varianssista. Faktorirakenne on selkeä, vaikka osalla muuttujista oli pieniä latauksia useammalle faktorille (taulukko 2). Muodostetuista kolmesta faktorista faktori 1 kuvaa sosiaalista ja ympäristövastuuta, faktori 2 työhyvinvointiin ja viihtymiseen liittyviä asioita ja faktori 3 taloudellisia arvoja, kuten voiton maksimointia ja parempaa elintasoa. 
Taulukko 1. Eri ryhmien ominaisuudet.

\begin{tabular}{|c|c|c|c|c|}
\hline & Aloitusvaihe & Keskivaihe & Myöhäinen vaihe & $\mathbf{p}$ \\
\hline \multicolumn{5}{|c|}{ Yrittäjän taustatietoja } \\
\hline $\mathrm{n}$ & 64 & 86 & 93 & \\
\hline Ikä, vuotta (ka) & 37,3 & 47,7 & 57,5 & $* *$ \\
\hline Kokemus, vuotta (ka) & 5,09 & 17,36 & 29,34 & $* *$ \\
\hline Milloin aloittanut viljelyn (keskiarvo) & 2004 & 1992 & 1981 & $* *$ \\
\hline $\begin{array}{l}\text { Tulonmuodostus (\% vastaajista) } \\
>75 \% \text { perheen tuloista viljelystä } \\
<25 \% \text { perheen tuloista viljelystä }\end{array}$ & $\begin{array}{l}39 \% \\
20 \% \\
\end{array}$ & $\begin{array}{l}45 \% \\
24 \% \\
\end{array}$ & $\begin{array}{l}42 \% \\
23 \% \\
\end{array}$ & \\
\hline $\begin{array}{l}\text { Koulutus (\% vastaajista) } \\
\text { Yliopisto tai korkeakoulu } \\
\text { Opisto } \\
\text { Ammattikoulu } \\
\text { Kursseja } \\
\text { Ei koulutusta }\end{array}$ & $\begin{array}{l}39 \% \\
25 \% \\
31 \% \\
5 \% \\
0 \% \\
\end{array}$ & $\begin{array}{l}10 \% \\
30 \% \\
52 \% \\
2 \% \\
6 \% \\
\end{array}$ & $\begin{array}{l}12 \% \\
28 \% \\
38 \% \\
11 \% \\
10 \% \\
\end{array}$ & $* * \mathrm{c}$ \\
\hline \multicolumn{5}{|c|}{ Tietoa tiloista } \\
\hline $\begin{array}{l}\text { Tuotantosuunta (\% vastaajista) } \\
\text { Kotieläintalous } \\
\text { Peltoviljely } \\
\text { Puutarha } \\
\text { Muu }\end{array}$ & $\begin{array}{l}21 \% \\
66 \% \\
2 \% \\
11 \%\end{array}$ & $\begin{array}{l}17 \% \\
73 \% \\
8 \% \\
1 \%\end{array}$ & $\begin{array}{l}18 \% \\
70 \% \\
8 \% \\
5 \%\end{array}$ & \\
\hline Tiloista monialaisia ( \%) & $25 \%$ & $30 \%$ & $26 \%$ & \\
\hline Henkilöstö, HTV & 1,6 & 1,5 & 1,5 & \\
\hline Liikevaihto, 1000 euroa $(\mathrm{ka})$ & 144,23 & 107,32 & 83,66 & \\
\hline $\begin{array}{l}\text { Kannattavuus verrattuna muihin } \\
\text { saman tuotantosuunnan tiloihin } \\
\text { (arvio1-5; } 1 \text { = paljon heikompi, } \\
5 \text { = paljon parempi) }\end{array}$ & 2,81 & 3,06 & 2,73 & $*$ \\
\hline 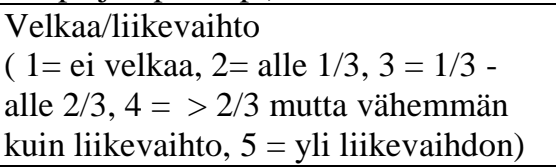 & 3,6 & 2,93 & 2,01 & $* *$ \\
\hline $\begin{array}{l}\text { Investoinnit maatalouteen, } 1000 \text { euroa } \\
\text { (keskiarvo) }\end{array}$ & 91,00 & 52,16 & 28,27 & $* *$ \\
\hline
\end{tabular}

$*=\mathrm{p}<0,05, * *=\mathrm{p}<0,01, \mathrm{c}=$ chi square-testi, muuten Kruskall-Wallisin ei-parametrinen testi

Taulukko 2. Rotatoitu faktorimatriisi.

\begin{tabular}{|l|c|c|c|}
\hline & \multicolumn{3}{|c|}{ Faktori } \\
\hline & $\mathbf{1}$ & $\mathbf{2}$ & $\mathbf{3}$ \\
\hline Kotimainen tuotanto & $\mathbf{0 , 6 5 8}$ & 0,134 & 0,059 \\
\hline Luonnon kunnioittaminen & $\mathbf{0 , 6 3 6}$ & 0,216 & 0,083 \\
\hline Maaseudulla asuminen & $\mathbf{0 , 6 2 6}$ & 0,466 & 0,040 \\
\hline Oma hyvinvointi & $\mathbf{0 , 5 6 1}$ & 0,250 & 0,250 \\
\hline Perheyrityksen jatkuvuus & $\mathbf{0 , 4 0 6}$ & 0,088 & 0,231 \\
\hline Itsenäinen työ & 0,213 & $\mathbf{0 , 8 4 8}$ & 0,068 \\
\hline Laadukas työ & 0,310 & $\mathbf{0 , 5 7 8}$ & 0,161 \\
\hline Itsenäinen toimeentulo & 0,173 & $\mathbf{0 , 5 4 2}$ & 0,228 \\
\hline Parempi elintaso itselle ja perheelle & 0,174 & 0,088 & $\mathbf{0 , 7 7 9}$ \\
\hline Voiton maksimointi & 0,065 & 0,104 & $\mathbf{0 , 7 1 5}$ \\
\hline Taloudellinen kannattavuus & 0,156 & 0,183 & $\mathbf{0 , 6 2 3}$ \\
\hline
\end{tabular}


Aloitusvaiheessa olevien viljelijöiden tavoitteet olivat melko samanlaisia kuin muidenkin viljelijöiden. He arvostivat hieman vähemmän sosiaalisia ja ympäristövastuuseen liittyviä tavoitteita sekä työhyvinvointia, toisaalta taloudelliset tavoitteet hieman korostuivat aloitusvaiheessa (taulukko 3a). Salon seudun viljelijät kokivat onnistuneensa sekä vastuullisuuteen että työhyvinvointiin liittyvissä tavoitteissa, mutta talouteen liittyvissä asioissa he kokivat epäonnistuneensa. Etenkin monet aloitusvaiheen viljelijät kokivat epäonnistuneensa tavoitteissaan. Huolestuttavaa on, että edes myöhäisessä vaiheessa olevat viljelijät eivät olleet tyytyväisiä taloudelliseen menestymiseensä, sillä tämä saattaa vaikuttaa myös tuleviin sukupolvenvaihdoksiin.

Taulukko 3a. Strategiset tavoitteet.

\begin{tabular}{|l|c|c|c|l|}
\hline & Aloitusvaihe & Keskivaihe & Myöhäinen vaihe & $p$ \\
\hline Sosiaalinen ja ympäristövastuu & $-0,06$ & $-0,02$ & 0,04 & \\
\hline Työhyvinvointi & $-0,24$ & 0,12 & 0,06 & $*$ \\
\hline Taloudelliset tavoitteet & 0,15 & 0,06 & $-0,17$ & \\
\hline
\end{tabular}

$*=\mathrm{p}<0,05$, Kruskall-Wallis ei parametrinen testi

Taulukko 3b. Menestyminen tavoitteissa.

\begin{tabular}{|l|c|c|c|l|}
\hline & Aloitusvaihe & Keskivaihe & Myöhäinen vaihe & $\mathrm{p}$ \\
\hline Sosiaalinen ja ympäristövastuu & 3,60 & 3,76 & 3,80 & \\
\hline Työhyvinvointi & 3,56 & 3,74 & 3,87 & $*$ \\
\hline Taloudelliset tavoitteet & 2,79 & 2,89 & 2,94 & \\
\hline
\end{tabular}

$*=p<0,05$, Kruskall-Wallisin ei-parametrinen testi

\section{Kehittämissuunnitelmat}

Postikyselyssä kysyttiin myös tilan kehittämissuunnitelmia seuraavan viiden vuoden aikana (taulukko 4). Aloitusvaiheessa olevilla yrittäjillä oli luonnollisesti paljon enemmän kehittämissuunnitelmia kuin muilla ryhmillä. Edes aloitusvaiheessa olevat viljelijät eivät kuitenkaan nähneet lainkaan kehittämispotentiaalia useimmissa kysytyissä asioissa, kuten uusien asiakkaiden löytämisessä. Yleisimmin suunnitelmat liittyivät itse tuotantoon, kuten uusien tuotantomenetelmien käyttöönottamiseen tai kapasiteetin lisäämiseen.

Table 4. Tilojen kehittämissuunnitelmat $(1=$ hyvin pieni todennäköisyys, $5=$ erittäin suuri todennäköisyys).

\begin{tabular}{|l|c|c|c|l|}
\hline & Aloitusvaihe & Keskivaihe & $\begin{array}{c}\text { Myöhäinen } \\
\text { vaihe }\end{array}$ & \multicolumn{1}{|c|}{ p } \\
\hline Asiakkaiden määrän lisääminen & 2,85 & 2,36 & 1,90 & ** \\
\hline Uusien tuotantomenetelmien käyttöönotto & 3,33 & 2,81 & 2,32 & ** \\
\hline Uusien jakelu- tai myyntikanavien käyttöönotto & 2,98 & 2,65 & 2,08 & ** \\
\hline Kapasiteetin lisääminen & 3,30 & 2,63 & 2,02 & ** \\
\hline Työvoiman lisääminen & 2,36 & 1,87 & 1,51 & ** \\
\hline Yritys- tai tilayhteistyön lisääminen & 3,05 & 2,58 & 2,01 & ** \\
\hline Töiden ulkoistamisen lisääminen & 2,73 & 2,13 & 1,83 & ** \\
\hline Tuotteiden/palvelujen kehittäminen/lisääminen & 3,19 & 2,63 & 2,23 & ** \\
\hline Toimialojen/tuotantosuuntien lisääminen & 2,55 & 2,20 & 1,78 & ** \\
\hline Sukupolvenvaihdos & 1,13 & 1,39 & 2,30 & * \\
\hline $\begin{array}{l}\text { Luopuminen jostain yritystoiminnan osasta tai } \\
\text { toimialojen/tuotantosuuntien karsiminen }\end{array}$ & 2,01 & 2,12 & 2,56 & ** \\
\hline
\end{tabular}

$*=p<0,05, * *=p<0,01$, muuten Kruskall-Wallisin ei-parametrinen testi 
Huomionarvoista oli, että monet myöhäisen vaiheen viljelijät eivät aikoneet kehittää tilaansa lainkaan seuraavien viiden vuoden aikana. Kehittämisaktiivisuudessa $e i$ myöskään ollut eroja niiden tilojen välillä, jotka aikoivat tehdä sukupolvenvaihdoksen verrattuna niihin tiloihin, joilla ei ollut jatkajaa tiedossa. Tulos on päinvastainen joihinkin aikaisempiin tutkimuksiin verrattuna (Gasson ja Errington 1993).

Viimeiseksi tarkasteltiin viljelijöiden näkemyksiä verkostoista sekä heidän omista verkostoitumistaidoistaan (taulukko 5). Tulosten mukaan aloitusvaiheen viljelijät ovat tässä suhteessa paremmin varustautuneita kuin vanhemmat sukupolvet. Aloitusvaiheen viljelijät arvostivat verkostoitumista enemmän kuin muut ryhmät, verkostojen luominen oli heille helpompaa kuin muille ryhmille ja he myös pitivät verkostojaan parempina kuin muut viljelijät. Tämä tulos vastaa esim. Goldbergin (1996) aiempia tuloksia.

Taulukko 5. Verkostoituminen ( 1 = täysin eri mieltä, 5 = täysin samaa mieltä).

\begin{tabular}{|l|c|c|c|c|}
\hline & Aloitusvaihe & Keskivaihe & $\begin{array}{c}\text { Myöhäinen } \\
\text { vaihe }\end{array}$ & p \\
\hline Verkostot ovat tärkeitä yritykselleni & 3,83 & 3,59 & 3,33 & $* *$ \\
\hline Verkostojen luominen on helppoa & 3,06 & 2,74 & 2,67 & $* *$ \\
\hline Yritykselläni on tällä hetkellä hyvät verkostot & 3,45 & 3,12 & 2,93 & $* *$ \\
\hline
\end{tabular}

$* *=\mathrm{p}<0,01$, Kruskall-Wallisin ei-parametrinen testi

\section{Johtopäätökset}

Tämän tutkimuksen tavoitteena oli selvittää miten hiljattain tilanpidon aloittaneet viljelijät eroavat kokeneemmista viljelijöistä eräiden tärkeimpien liikkeenjohdon osa-alueiden, kuten tilan ja viljelijän ominaisuuksien, strategisten tavoitteiden ja kehittämissuunnitelmien, suhteen. Tutkimusaineisto kerättiin postikyselynä Salon kaupungin alueelta Lounais-Suomesta marraskuussa 2010. Tutkimusaineistossa on mukana 237 tilan vastaukset. Tutkimusaineisto analysoitiin käyttäen hyväksi $\chi 2$ - testiä, Kruskall-Wallisin testiä, exploratiivista faktorianalyysia sekä ryhmittelyanalyysiä. Viljelijät jaettiin tutkimuksessa kolmeen ryhmään kokemuksen ja iän perusteella. Muodostetut kolme ryhmää olivat: Aloitusvaihe, keskivaihe ja myöhäinen/luopumis -vaihe.

Tulosten perusteella aloittelevat viljelijät ovat joidenkin ominaisuuksien suhteen paremmassa asemassa kuin vanhemmat viljelijät. Heillä on mm. parempi koulutus sekä paremmat verkostot kuin muilla viljelijöillä. Ennakko-oletusten mukaisesti aloittelevat viljelijät ovat investoineet viime vuosina enemmän ja heillä on enemmän velkaa kuin muilla viljelijöillä. Heidän tilansa ovat myös heikommin kannattavia kuin muiden viljelijöiden tilat.

Strategisen liikkeenjohdon tavoitteet olivat jossain määrin samanlaisia kaikilla Salon alueen tiloilla riippumatta yritystoiminnan elinkaaren vaiheesta. Kuitenkin aloittelevat viljelijät arvostivat taloudellisia tavoitteita jossain määrin enemmän ja sosiaalisen ja ympäristövastuun tavoitteita sekä työhyvinvointiin liittyviä tavoitteita hiukan vähemmän kuin muut viljelijät. Yleisesti aloittelevat viljelijät arvioivat oman suorituksensa suhteessa asettamiinsa tavoitteisiin heikommaksi kuin muut viljelijät.

Aloittelevat viljelijät kehittivät tilojaan aktiivisimmin ja luopumisvaiheen viljelijät vähiten. Edes tiloilla, joilla oli tarkoitus toteuttaa sukupolvenvaihdos viiden seuraavan vuoden aikana, ei ollut muita kehittämissuunnitelmia. Tämä tulos on ristiriitainen aikaisempien tutkimusten tulosten kanssa. Tulos on myös ongelmallinen tilanpidon jatkajien kannalta, sillä mikäli edes välttämättömiä korvausinvestointeja ei ole tehty, joka sukupolven täytyy investoida rajusti heti sukupolvenvaihdoksen jälkeen. Koko maataloussektorin elinvoimaisuus paranisi, jos tilan ja viljelijän elinkaaret voitaisiin erottaa toisistaan ja tiloja kehitettäisiin jatkuvasti elinkaaren vaiheesta huolimatta.

Tämän tutkimuksen tulokset tukevat aikaisempia tutkimustuloksia verkostojen tärkeydestä aloitteleville viljelijöille. Lisäksi aloittelevat viljelijät pitävät omia verkostojaan tärkeämpinä kuin heidän vanhemmat viljelijäkollegansa. 


\section{Kirjallisuus}

Cuykendal, C., LaDue, E. \& Smith, D.R. 2002. What successfull small farmers say. The results of a survey of successful small farm operators. R.B. 2002-01. Ithaca, New York: Agricultural Finance and Management at Cornell.

Diwisch, S., Voithofer, P. and Weiss, C. 2009. Succession and firm growth: results from non-parametric matching approach. Small Business Economics (1); 32: 45-56.

Gasson, R. \& Errington, A. 1993. The Farm Family Business. CAB International. 290 s.

Goldberg, S.D. 1996. Research Note: Effective Successors in Family-Owned Businesses: Significant Elements. Family Business Review, vol. 9, no. 2: 185-197.

Hirvi, T.2004a. Aktiivitilojen viljelijöiden mielipiteitä investointituesta ja nuorten viljelijöiden aloitustuesta, MTT:n selvityksiä 79 (2004). 60 s.

Hirvi, T. 2004b. Nuorten viljelijöiden tulonmuodostus ja työnkäyttö. MTT:n selvityksiä $65.66 \mathrm{~s}$.

Kimhi, A. \& Lopez, R. A Note on Farmers' Retierement and Succession Considerations: Evidence from a Household Survey. Journal of Agricultural Economics 50: 154-162.

Littunen, M., Storhammar, E. and Nenonen, T. 1998. The survival of firms over the critical first years and the local environment. Entrepreneurship \& Regional Development, 10; 189-202.

Ondersteijn, C.J.M, Giesen, G.W.J. and Huirne, R.B.M. 2003. Identification of farmer characteristics and farm strategies explaining changes in environmental management and environmental and economic performance of dairy farms. Agricultural Systems 78: 31-55.

Rantamäki-Lahtinen, L. 2007. Hajauttamisen pitkän aikavälin vaikutukset monialaisilla tiloilla vertailututkimus Suomesta ja Englannista. Julkaisussa: Juntti, L. ja Rantamäki-Lahtinen, L. 2007. Monialaisuus maaseutuyrityksen mahdollisuutena. MTT:n selvityksiä 145. $62 \mathrm{~s}$.

Väre, M. 2007. Determinants of farmer retirement and farm succession in Finland. Agrifood Research Reports 93. Agrifood Research Finland. 109 s.

Väre, M. 2010. Sukupolvenvaihdokset ja Lutu-järjestelmä. Julkaisussa: Maataloustieteen Päivät 2010. Suomen Maataloustieteellisen Seuran julkaisuja no 26. Toim. Anneli Hopponen. Saatavilla: http://www.smts.fi

Weiss, C.R. 1999. Farm Growth and Survival: Econometric Evidence for Individual Farms in Upper Austria. Amer. J. Agr. Econ. 81 (February): 103.116. 